\title{
Baseline malaria vector transmission dynamics in communities in Ahafo mining area in Ghana
}

Dominic B Dery ${ }^{1 *}$, Kwaku P Asante ${ }^{1}$, Charles Zandoh ${ }^{1}$, Lawrence G Febir ${ }^{1}$, Charles Brown², George Adjei',

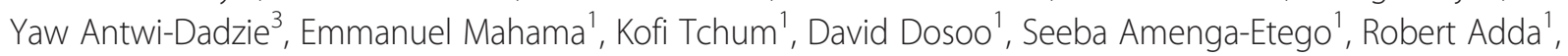
Christine Mensah ${ }^{4}$, Kwabena B Owusu-Sekyere ${ }^{3}$, Chris Anderson ${ }^{3}$, Gary Krieger ${ }^{5}$ and Seth Owusu-Agyei ${ }^{1}$

\begin{abstract}
Background: Malaria vector dynamics are relevant prior to commencement of mining activities. A baseline entomology survey was conducted in Asutifi and Tano (referred to as Ahafo) in the Brong-Ahafo geo-political region of Ghana during preparatory stages for mining by Newmont Ghana Gold Limited.

Methods: Between November 2006 and August 2007, eight Centre for Disease Control light traps were set daily (Monday-Friday) to collect mosquitoes. Traps were hanged in rooms that were selected from a pool of 1,100 randomly selected houses. Types of materials used in construction of houses were recorded and mosquito prevention measures were assessed from occupants.
\end{abstract}

Results: A total of 5,393 mosquitoes were caught that comprised Anopheles gambiae (64.8\%), Anopheles funestus (4.2\%), as well as Culicines, comprising of Culex (30.4\%) and Aedes species (0.6\%). The entomological inoculation rate in Asutifi (279 infective bites/person/month) and Tano (487 infective bites/person/month) demonstrate relatively high malaria transmission in Ahafo. The presence or absence of Anopheles vectors in rooms was influenced by the type of roofing material (OR 2.33, 95\% Cl: 1.29-4.22, $\mathrm{p}=0.01)$ as well as the presence of eaves gaps (OR 1.80, 95\%Cl: 1.37-2.37, $\mathrm{p}<0.01)$. It was also associated with bed net availability in the room (OR 1.39, $95 \% \mathrm{Cl}: 1.08-1.80, p=0.01)$. Over $80 \%$ of the houses were roofed with corrugated zinc sheets. Over $60 \%$ of the houses in Ahafo had no eaves gaps to give access to mosquito entry and exit into rooms and mosquito bed net coverage was over 50\%. Other measures used in preventing mosquito bites included; coil (22.1\%), insecticide spray $(9.4 \%)$, repellent cream (4.0\%) and smoky fires (1.1\%), contributed minimally to individual mosquito preventive measures in impact areas. Similarly, levels of protection; coil (16.9\%), insecticide spray (2.8\%) and repellent cream (0.3\%) for the non-impact areas, depict low individual prevention measures.

Conclusions: The survey identified areas where intensified vector control activities would be beneficial. It also demonstrates that transmission in Asutifi and Tano is high even before the commencement of mining operations. This study serves as baseline information to assess impact of mining activities in relation to future vector control interventions.

Keywords: Malaria transmission, Ahafo, Anopheles gambiae, Anopheles funestus

\footnotetext{
* Correspondence: bonereme@gmail.com

'Kintampo Health Research Centre, Ghana Health Service, Ministry of Health,

P.O. Box 200, Kintampo, Ghana

Full list of author information is available at the end of the article
} 


\section{Background}

Knowledge of vector bionomics is essential in understanding the epidemiology and implementing control of malaria [1]. Today, malaria can be prevented, diagnosed and treated with a combination of well-established strategies. Vector control is one of the key control tools and involves the use of insecticide-treated mosquito nets (ITN), indoor residual spraying and larval control activities [2]. Malaria vector control is an important strategy recognized in the global policy frameworks [3,4] of which Ghana is no exception.

Ghana is endowed with significant mineral deposits [5]. These deposits have attracted both large international mining companies and small-scale artisanal miners. Mining activities can lead to land degradation, changes in landscape, deforestation and changes in human behaviour [6]. More importantly, mining activities may lead to a change in the abundance and distribution of malaria vectors $[7,8]$. Mining activities may also lead to enhanced household income and improved housing construction, which can impact on malaria transmission.

The attraction of mosquitoes into a house or room is dependent on various factors including construction materials and room characteristics $[9,10]$. Studies in Sri Lanka and Kenya [11,12] found that the risk of getting malaria was greater for inhabitants occupying the poorest type of houses which was characterized by incomplete construction with thatched roofs and walls made of mud or cadjan (woven coconut palm leaves). This was compared with better-constructed houses made of complete brick and plastered walls and tiled roofs. The Kenyan study specifically found $84 \%$ (OR $0.16,95 \%$ CI $0.07-0.39, \mathrm{P}<0.0001$ ) and $87 \%$ (OR 0.13, 95\% CI 0.03-0.5, $\mathrm{P}=0.0004$ ) reduction in the odds of finding Anopheles gambiae s.l. and Anopheles funestus in better constructed houses compared with poorly constructed houses [13]. Thus, malaria transmission may be affected by improvement in housing construction as a result of enhanced income generation in mining areas.

Malaria assessment, including vectorial capacity determination, are important prior to introduction of mining activities as this will inform monitoring of vector dynamics over time so as to plan effective control interventions. Prior to the start of active mining in the Ahafo area of Ghana, Newmont Gold Ghana Ltd (NGGL) commissioned a variety of environmental, social and health baseline studies. The present study was commissioned by NGGL in order to determine basic malaria entomological indices including transmission dynamics in the mining area.

\section{Methods}

\section{Study areas and communities}

The study was conducted in two areas in the Brong Ahafo Region of Ghana; Asutifi and Tano (Figure 1). Asutifi lies between latitudes $6^{\circ} 40^{\prime}$ and $7^{\circ} 15^{\prime}$ North and Longitudes $2^{\circ} 15^{\prime}$ and $2^{\circ} 45^{\prime}$ West. Tano lies between latitudes $7^{\circ} 00^{\prime} \mathrm{N}$ and $7^{\circ} 25^{\prime} \mathrm{N}$ and between longitudes $1^{\circ} 45 \mathrm{~W}$ and $2^{\circ} 30 \mathrm{~W}$. Asutifi had a population of approximately 97,977 and land surface area of 1,500 square kilometres. Tano had a total population of approximately 155,100 at the time of survey. The study area falls within the wet semi-equatorial forest zone where mean annual rainfall is about $1200 \mathrm{~mm}$ per annum. The quarterly rainfall pattern in the area (Figure 2) depicts rainfall throughout the year and reflects two raining seasons in the area. The major economic activities in the study areas besides gold mining are farming of cash crops, such as cocoa, palm oil, yam and plantain.

Studied communities were grouped into "impact" and "non-impact" communities based on the assumption that mining operations could have an impact on the health and socio-economic status of the population. "Impact" area means communities either in the Asutifi or Tano area whose health and/or socio-economic indices are likely to be directly affected by mining activities being undertaken and located within $25 \mathrm{Km}$ radius from the mine sites. The "non-impact" area represents communities in either the Asutifi or Tano areas that are not likely to be affected directly by the mining activities and located outside the 25 kilometres radius from the mines site.

The area has a health system conforming to the basic primary care model established by the Ghana Health Service. Communities are served by a local health clinic that manages basic health problems. All health facilities in the study area render both clinical and public health services. Malaria is the leading reported cause of outpatient attendance in all health facilities in the study area.

\section{Study design and methods}

Houses were randomly selected from among those used in a district-wide household morbidity survey [14] and mosquito traps were set using CDC light traps. All the houses in the morbidity survey that had children less than five years of age formed the sampling frame from which rooms were selected for the mosquito light trappings.

A total of 1,100 houses were randomly selected from enumerated houses in the Asutifi and Tano areas and used for the weekly trappings. Eight CDC light traps were set daily; four were set simultaneously in Asutifi and Tano respectively, starting from November 2006 and ending in August 2007. Traps were set at the foot-end of the person (s) sleeping in the selected room and hanged approximately 1.6 metres above the floor. Untreated mosquito nets were provided to household members whose rooms were used on the night of trap setting as an ethical requirement.

The characteristics were recorded for each house where a trap was set; these included the types of materials used for roof construction, walls and floor; presence of eaves 


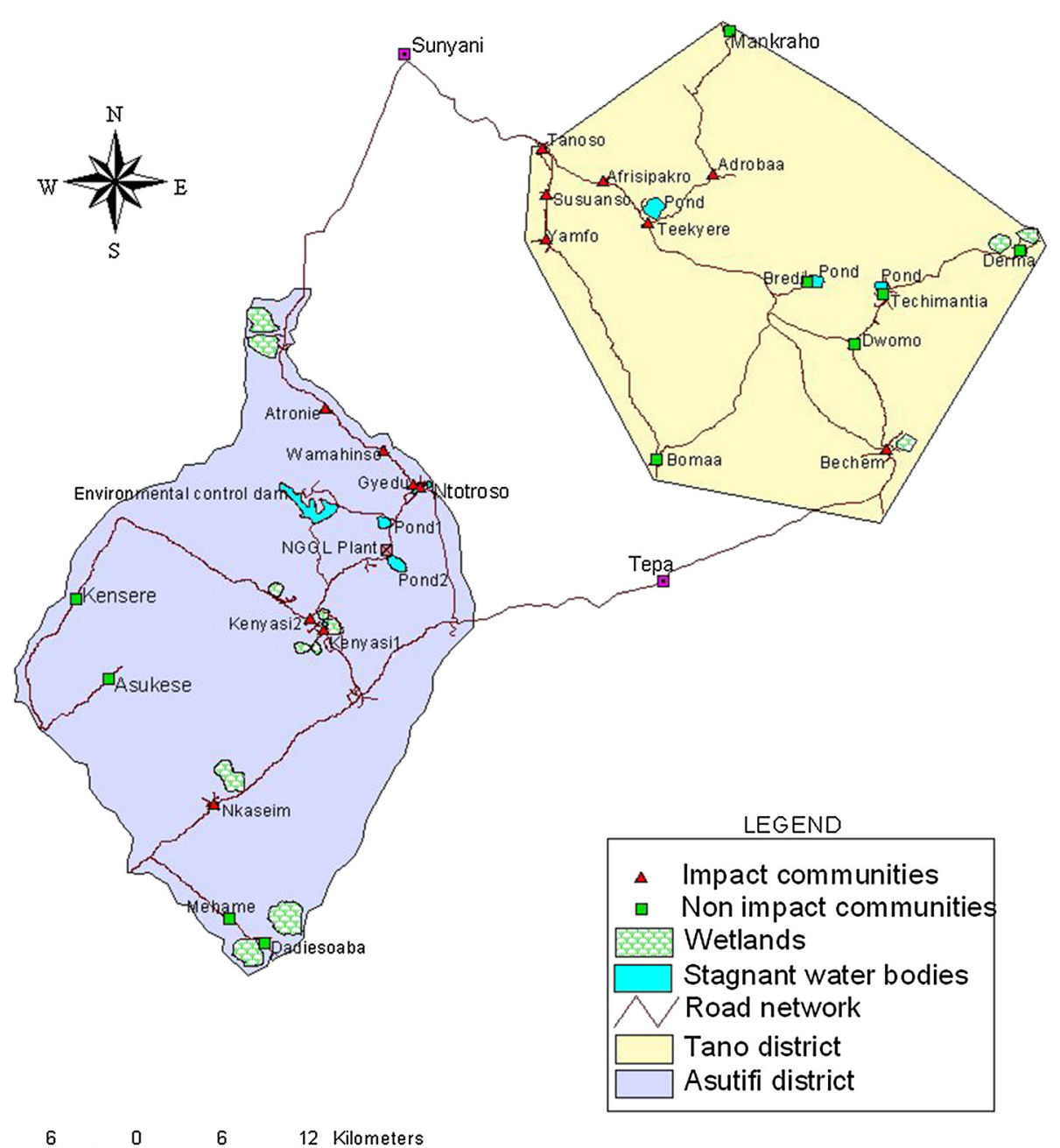

Figure 1 Map of Asutifi and Tano area in Ghana (Nov 2006-Aug 2007).

Ave rainfall $(\mathrm{mm})$

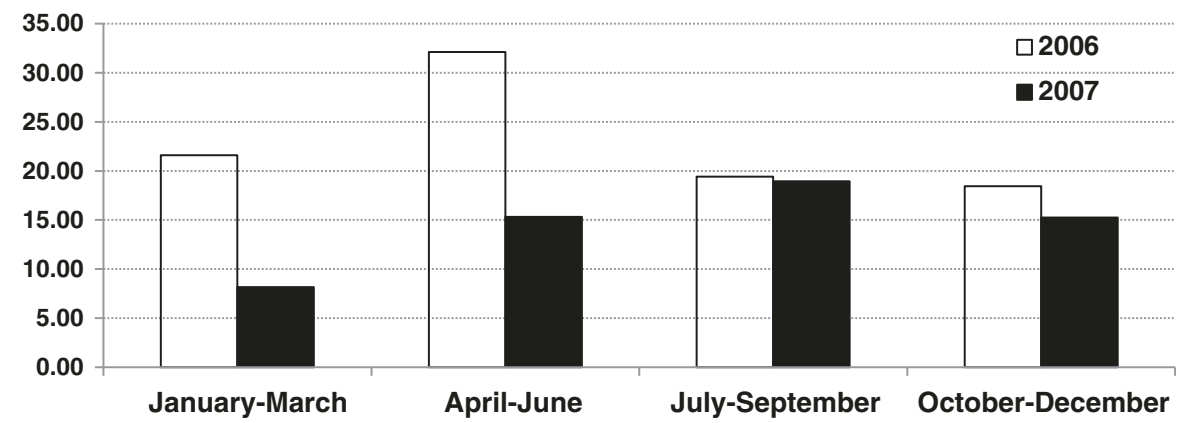

Figure 2 Bi-monthly rainfall pattern in Asutifi and Tano area in Ghana (2006-2007). 
gaps, number of windows and doors. Malaria vector preventive measures were assessed one week prior to the date of survey on occupants in each room that received a light trap.

Mosquitoes caught were chloroformed and morphologically identified using Anopheline morphological identification keys [15]. They were then stored in $1.5 \mathrm{ml}$ eppendorf tubes and transported on weekly basis to the Kintampo Health Research Centre laboratories for enzyme-linked immunosorbent assay (ELISA) [16]. An average cut-off point of $0.2 \mathrm{~nm}$ absorbance wavelength was considered positive. Positive samples were re-tested for confirmation.

\section{Data management}

All data collected in the field or the laboratory were logged for traceability, and then batched for double data entry and processing using Microsoft ${ }^{\bullet}$ Access.

\section{Statistical analysis}

The entomological inoculation rate (EIR) was calculated as the product of the proportion of Anopheles positive by ELISA also termed as sporozoite rate (SR) and the man biting rate, which was estimated as the geometric mean of Anopheles caught by CDC light traps per night. The monthly EIR (EIRm) was calculated as the product of EIR for a night (EIRn) and estimated number of days in a month (30). The presence or absence of Anopheline species in houses in relation to housing construction and location was modeled using logistic regression controlling for the main confounding variables.

\section{Ethics}

Approval for the study was obtained from the Kintampo Institutional Ethics Committee (Federal Wide Assurance number: 00011103). Participants were consented the night before setting a light trap. Untreated mosquito nets were provided to occupants of rooms on the night of setting trap to ensure they were protected while ensuring that mosquitoes were not repelled. The Kintampo Health Research Centre ethics committee approved this method.

\section{Results}

Mosquito vector abundance and EIRs in Asutifi and Tano A total of 942 CDC light trap-nights were set within the period (November 2006 - August 2007). A total of 5,393 mosquitoes were collected which comprised An. gambiae (64.8\%), An. funestus (4.2\%), Culex species (30.4\%) and Aedes species (0.6\%). Mosquito abundance was generally higher in the impact areas of Asutifi compared with the non-impact areas (Table 1). Ntotroso recorded the highest number of mosquitoes caught in the impact area and Mehame recorded the highest mosquitoes caught in non-impact area. An. gambiae and An. funestus vector abundance in the two areas were significantly different. Anopheles gambiae was much higher (ten-fold) in impact areas compared to An. funestus. However, in non-impact areas abundance of both species were nearly equal.

Relatively higher numbers of mosquitoes were caught in non-impact areas than impact areas in Tano (Table 2). Afisipakrom recorded the highest number of mosquitoes caught in impact area and Bredi recorded the highest

Table 1 Mosquito abundance and EIRs in Asutifi area in Ghana (Nov 2006 - Aug 2007)

\begin{tabular}{|c|c|c|c|c|c|c|c|c|c|c|c|}
\hline Location & VILLAGE & $\begin{array}{l}\text { An. gambiae } \\
n(\%)\end{array}$ & $\begin{array}{l}\text { An. funestus } \\
n(\%)\end{array}$ & $\begin{array}{l}\text { Culex sp. } \\
\text { n (\%) }\end{array}$ & $\begin{array}{l}\text { Aedes sp. } \\
\text { n (\%) }\end{array}$ & SR-Ag & SR-Af & SR & MBR & EIRn & $\overline{E I R m}$ \\
\hline \multirow[t]{7}{*}{ IMPACT } & ATRONIE & $41(4.7)$ & $1(0.5)$ & $47(4.6)$ & $7(50.0)$ & 0.1 & 0.0 & 0.1 & 6.0 & 0.6 & 18.0 \\
\hline & GYEDU & $48(5.5)$ & $13(6.8)$ & $81(7.9)$ & $0(0.0)$ & 0.3 & 0.0 & 0.3 & 17.0 & 4.3 & 127.5 \\
\hline & KENYASI NO.2 & $44(5.1)$ & $2(1.1)$ & 108 (10.6) & $0(0.0)$ & 0.3 & 0.0 & 0.3 & 2.0 & 0.5 & 15.0 \\
\hline & NKASEIM & $67(7.7)$ & $42(22.1)$ & $95(9.3)$ & $1(7.1)$ & 0.1 & 0.1 & 0.2 & 7.0 & 1.2 & 35.7 \\
\hline & NTOTROSO & 309 (35.7) & $14(7.4)$ & $175(17.2)$ & $6(42.9)$ & 0.1 & 0.0 & 0.1 & 8.0 & 0.3 & 9.6 \\
\hline & WAMAHINSO & $38(4.4)$ & $1(0.5)$ & $48(4.7)$ & $0(0.0)$ & 0.1 & 0.0 & 0.1 & 6.0 & 0.3 & 9.0 \\
\hline & KENYASI NO.1 & $201(23.2)$ & $16(8.4)$ & $125(12.3)$ & $0(0.0)$ & 0.1 & 0.1 & 0.2 & 8.0 & 1.0 & 31.2 \\
\hline \multirow[t]{6}{*}{ NON-IMPACT } & ASUKESE & $34(3.9)$ & $9(4.7)$ & 37 (3.6) & $0(0.0)$ & 0.2 & 0.0 & 0.2 & 5.0 & 0.8 & 24.0 \\
\hline & DADIESOABA & $50(5.8)$ & $25(13.2)$ & $102(10.0)$ & $0(0.0)$ & 0.1 & 0.0 & 0.1 & 17.0 & 1.4 & 40.8 \\
\hline & KENSERE & $11(1.3)$ & $34(17.9)$ & $48(4.7)$ & $0(0.0)$ & 0.2 & 0.0 & 0.0 & 5.0 & 0.2 & 6.0 \\
\hline & MEHAME & $22(2.5)$ & $33(17.4)$ & $153(15.0)$ & $0(0.0)$ & 0.1 & 0.0 & 0.1 & 7.0 & 0.6 & 16.8 \\
\hline & Total & 865 & 190 & 1,019 & 14 & 1.4 & 0.2 & 1.4 & 6.9 & 9.3 & 278.6 \\
\hline & TOTAL $^{a}$ & $2,088^{a}$ & & & & & & & & & \\
\hline
\end{tabular}

SR-Ag; Sporozoite Rate for An. gambiae, MBR; Man Biting Rate.

SR-Af; Sporozoite Rate for An. funestus, EIRn; Entomological Inoculation Rate/night.

EIRm; Entomological Inoculation Rate/month, SR; Sporozoite Rate (Ag + Af).

Superscript ( $\left.{ }^{a}\right)$ - Total mosquitoes caught in Asutifi n; number caught. 
Table 2 Mosquito abundance and EIRs in Tano area in Ghana (Nov 2006 - Aug 2007)

\begin{tabular}{|c|c|c|c|c|c|c|c|c|c|c|c|}
\hline Location & VILLAGE & $\begin{array}{l}\text { An. gambiae } \\
\mathrm{n}(\%)\end{array}$ & $\begin{array}{l}\text { An. funestus } \\
\mathrm{n}(\%)\end{array}$ & $\begin{array}{l}\text { Culex sp. } \\
\mathrm{n}(\%)\end{array}$ & $\begin{array}{l}\text { Aedes sp. } \\
\mathrm{n}(\%)\end{array}$ & SR-Ag & SR-Af & SR & MBR & EIRn & EIRm \\
\hline \multirow[t]{7}{*}{ IMPACT } & ADROBAA & $94(3.6)$ & $1(2.7)$ & $20(3.2)$ & $0(0.0)$ & 0.1 & 0.0 & 0.1 & 11.0 & 0.6 & 16.5 \\
\hline & AFISIPAKROM & $448(17.0)$ & $2(5.4)$ & $23(3.7)$ & $0(0.0)$ & 0.1 & 0.0 & 0.1 & 36.0 & 1.8 & 54.0 \\
\hline & BECHEM & $93(3.5)$ & $3(8.1)$ & $182(29.4)$ & $0(0.0)$ & 0.1 & 0.0 & 0.1 & 6.0 & 0.8 & 23.4 \\
\hline & SUSUANSO & $17(0.6)$ & $1(2.7)$ & $24(3.9)$ & $0(0.0)$ & 0.1 & 0.0 & 0.1 & 4.0 & 0.2 & 7.2 \\
\hline & TEEKYEERE & $61(2.3)$ & $1(2.7)$ & $10(1.6)$ & $0(0.0)$ & 0.2 & 0.0 & 0.2 & 8.0 & 1.2 & 36.0 \\
\hline & TANOSO & $27(1.0)$ & $1(2.7)$ & $31(5.0)$ & $1(50.9)$ & 0.2 & 0.0 & 0.2 & 4.0 & 0.7 & 21.6 \\
\hline & YAMFO & $18(0.7)$ & $0(0.0)$ & $45(7.3)$ & $1(50.9)$ & 0.3 & 0.0 & 0.3 & 3.0 & 0.8 & 25.2 \\
\hline \multirow[t]{10}{*}{ NON-IMPACT } & BOMAA & $69(2.6)$ & $5(13.5)$ & $43(6.9)$ & $8(47.1)$ & 0.3 & 0.0 & 0.3 & 5.0 & 1.5 & 45.0 \\
\hline & BREDI & $1321(50.2)$ & $0(0.0)$ & $16(2.6)$ & $0(0.0)$ & 0.0 & 0.0 & 0.0 & 274.0 & 5.5 & 164.4 \\
\hline & DERMA & $147(5.6)$ & $1(2.7)$ & $104(16.8)$ & $1(5.9)$ & 0.1 & 0.0 & 0.1 & 11.0 & 1.1 & 33.0 \\
\hline & DWOMO & $217(8.2)$ & $13(35.1)$ & $39(6.3)$ & $1(5.9)$ & 0.0 & 0.0 & 0.0 & 31.0 & 0.9 & 27.9 \\
\hline & MANKRAHO & $64(2.4)$ & $8(21.6)$ & $64(10.3)$ & $4(23.5)$ & 0.2 & 0.0 & 0.2 & 6.0 & 1.0 & 28.8 \\
\hline & TECHIMANTIA & $56(2.1)$ & $1(2.7)$ & $18(2.9)$ & $1(5.9)$ & 0.1 & 0.0 & 0.1 & 4.0 & 0.4 & 13.2 \\
\hline & Total & 2,632 & 37 & 619 & 17 & 1.7 & 0 & 1.6 & & & 486.8 \\
\hline & TOTAL ${ }^{\mathrm{b}}$ & $3,305^{b}$ & & & & & & & & & \\
\hline & & $3,497(64.8)$ & $227(4.2)$ & $1,638(30.4)$ & $31(0.6)$ & & & & & & \\
\hline & TOTAL (Tano + Asutifi) & 5,393 & & & & & & & & & \\
\hline
\end{tabular}

SR-Ag; Sporozoite Rate for An. gambiae, MBR; Man Biting Rate.

SR-Af; Sporozoite Rate for An. funestus, EIRn; Entomological Inoculation Rate/night.

EIRm; Entomological Inoculation Rate/month, SR; Sporozoite Rate (Ag + Af).

Superscripts $\left({ }^{\mathbf{b}}\right)$ - Total mosquitoes caught in Tano $\mathbf{n}$; number caught.

number of mosquitoes in non-impact area. Most Anopheles vectors caught were $A n$. gambiae with nearly negligible numbers of $A n$. funestus vectors.

EIRs were higher for An. gambiae than An. funestus in both impact and non-impact areas in Asutifi (Table 1). A similar trend is observed in Tano (Table 2). EIR per month in Asutifi ranged between nine infective bites/person/ month and $128 \mathrm{ib} / \mathrm{p} / \mathrm{m}$ in impact area. In the non-impact area it ranged between $6-41 \mathrm{ib} / \mathrm{p} / \mathrm{m}$ (Table 1 ). EIRs in Tano ranged between $7-54 \mathrm{ib} / \mathrm{p} / \mathrm{m}$ in impact area and $13-164 \mathrm{ib} / \mathrm{p} / \mathrm{m}$ in non-impact area (Table 2).

\section{Housing characteristics and mosquito preventive measures}

Between $80 \%$ - 90\% of houses in the study area were roofed with corrugated zinc sheets; with $94.7 \%$ and $82.6 \%$ in impact and non-impact areas, respectively. A few houses were roofed with logs (1.8\% in impact, $7.7 \%$ in non-impact) and thatch (3.5\% in impact; $9.7 \%$ in nonimpact) (Table 3$)$. Over sixty percent $(67.5 \%)$ of houses in impact area had no eaves gaps compared with $62.9 \%$ of houses in non-impact area. Nearly half (48\%) of the houses surveyed had a bed net. In preventing mosquito bites, $22.1 \%$ of respondents used mosquito coils in impact areas as against $16.9 \%$ in non-impact areas. The use of insecticide sprays was $9.4 \%$ in impact areas and $2.8 \%$ in non-impact places. Four percent of respondents' applied repellent creams in impact areas but a negligible $0.3 \%$ applied creams in non-impact areas. A negligible number had used strongly scented leaves $(0.5 \%)$ or smoky fire $(1.1 \%)$ to prevent mosquito bites in impact areas but none was recorded in non-impact areas.

The types of construction materials correlated positively with high abundance of Anopheles in rooms, i.e. the presence of grass or thatch roof was associated with a significant increase in calculated odds ratio (Table 4). There was significant association in abundance of $A n$. gambiae and An. funestus at three levels; roof type, presence of eaves gaps and bed nets in rooms of individuals. The latter association (presence of bed nets) is further explained by the fact that majority of the nets were untreated.

\section{Discussion}

The abundance of mosquitoes in the two areas (Tano and Asutifi) differed slightly. Unlike Asutifi where mosquito abundance was highest in impact area of communities, Tano experienced the reverse within the surveyed period. This observation could be attributed to microecological differences and rainfall in the two areas. The total number of mosquitoes caught in this survey is high against the background of a relatively short period of collection. Similar surveys $[9,10,17]$ in which the period of collection was longer (one or two years) using the 
Table 3 Characteristics of houses and mosquito preventive measures by individuals in Ahafo area of Ghana (Nov 2006-Aug 2007)

\begin{tabular}{|c|c|c|c|}
\hline \multirow[t]{2}{*}{ Variables $(\mathrm{N}=942)$} & \multirow{2}{*}{$\begin{array}{l}\text { Impact }(\mathrm{N}=551) \\
\text { n (\%) }\end{array}$} & \multicolumn{2}{|c|}{ Non-impact $(\mathrm{N}=391)$} \\
\hline & & n (\%) & p-value \\
\hline \multicolumn{4}{|l|}{ Presence of eaves gaps } \\
\hline Yes & 179 (32.5) & $145(37.1)$ & 0.14 \\
\hline No & $372(67.5)$ & $246(62.9)$ & \\
\hline \multicolumn{4}{|l|}{ Type of roof } \\
\hline Corrugated zinc roof & $522(94.7)$ & $323(82.6)$ & $<0.01$ \\
\hline Mud concrete/logs roof & $10(1.8)$ & $30(7.7)$ & \\
\hline Thatch roof & $19(3.5)$ & $38(9.7)$ & \\
\hline \multicolumn{4}{|l|}{ Bed net use } \\
\hline Yes & $249(45.3)$ & $201(51.3)$ & 0.07 \\
\hline No & $301(54.7)$ & $191(48.7)$ & \\
\hline \multicolumn{4}{|l|}{ Insecticide spray } \\
\hline Yes & $52(9.4)$ & $11(2.8)$ & $<0.01$ \\
\hline No & 499 (90.6) & $380(97.2)$ & \\
\hline \multicolumn{4}{|l|}{ Mosquito coil } \\
\hline Yes & $122(22.1)$ & $66(16.9)$ & 0.05 \\
\hline No & $429(77.9)$ & $325(83.1)$ & \\
\hline \multicolumn{4}{|l|}{ Smoky fire } \\
\hline Yes & $6(1.1)$ & $0(0.0)$ & $0.04^{*}$ \\
\hline No & $545(98.9)$ & $391(100.0)$ & \\
\hline \multicolumn{4}{|l|}{ Scented leaves } \\
\hline Yes & $3(0.5)$ & $0(0.0)$ & $0.27^{*}$ \\
\hline No & $548(99.5)$ & $391(100.0)$ & \\
\hline \multicolumn{4}{|l|}{ Repellent creams } \\
\hline Yes & $22(4.0)$ & $1(0.3)$ & $<0.01^{*}$ \\
\hline No & $529(96.0)$ & $390(99.7)$ & \\
\hline
\end{tabular}

*: Fisher's Exact test. a: Pearson Chi-squared test.

same collection method (CDC light traps) produced lower mosquito collections.

There were more mosquitoes caught in mud/log and grass/thatched roofed houses compared to zinc corrugated roofed houses. This could be attributed to the conducive nature thatched roofed and mud houses present for mosquito entry. This observation could also be linked to the fact that these types of houses present conducive environment for mosquitoes to rest indoors. Improvement in socio-economic standards may result in improved housing architecture such as the use of window screens that can reduce malaria transmission by reducing man-vector contact. Eventually this could lead to a decreased mosquito burden inside rooms and subsequent decrease in malaria transmission levels.

EIRs in the surveyed communities demonstrate very high malaria transmission levels by Anopheles vectors
Table 4 Factors that influence abundance of Anopheles gambiae and Anopheles funestus in rooms in Ahafo area of Ghana (Nov 2006-Aug 2007)

\begin{tabular}{llll}
\hline Variables & $\begin{array}{l}\text { Number } \\
(\%)\end{array}$ & $\begin{array}{l}\text { Odds } \\
\text { ratio }\end{array}$ & $\begin{array}{l}95 \% \\
\text { Confidence } \\
\text { interval }\end{array}$ \\
\hline
\end{tabular}

Presence of eaves

gaps

No $302(49.0) \quad 1$

$\begin{array}{lllll}\text { Yes } & 206(63.4) & 1.80 & (1.37,2.37) & <0.01\end{array}$

Type of roof

Corrugated zinc roof $442(52.4) \quad 1$

Mud concrete/logs roof $25(62.5) \quad 1.52 \quad(0.79,2.92) \quad 0.01$

Thatch roof $\quad 41(71.9) \quad 2.33 \quad(1.29,4.22)$

Bed net use

No $246(50.0) \quad 1$

$\begin{array}{lllll}\text { Yes } & 262(58.2) & 1.39 & (1.08,1.80) & 0.01\end{array}$

Insecticide spray

No $\quad 468$ (53.3) 1

$\begin{array}{lllll}\text { Yes } & 40(63.5) & 1.52 & (0.90,2.59) & 0.12\end{array}$

Mosquito coil

No

Yes

$390(52.1) \quad 1$

$118(61.1) \quad 1.44 \quad(1.05,1.99) \quad 0.03$

Smoky fire

No

$502(53.8) \quad 1$

Yes

$6(85.7) \quad 5.16$

$(0.62,11.05) \quad 0.13$

Scented leaves

No

$505(53.8) \quad 1$

Yes

$3(0.59) \quad 0.44$

$(0.04,4.92) \quad 0.51$

Repellent creams

No

$493(53.7) \quad 1$

Yes

$15(65.2) \quad 1.62$

$(0.68,3.85) \quad 0.28$

Area

Impact

$290(52.7) \quad 1$

Non-Impact

$218(55.6) \quad 1.12$

$(0.87,1.46) \quad 0.38$

(7-128 infective bites per person per month). This is comparable with EIRs documented in the Kintampo area where the same investigators documented 269 infective bites per person per year [18]. EIRs varied significantly between communities; therefore, control strategies need to be planned in concert with detailed communities vector indices; abundance, speciation and EIRs. In Tano, EIRs in the impact communities were significantly higher in three of seven communities while in the non-impact communities two of six communities had higher EIRs.

Since infective An. gambiae vectors were detected by ELISA in each month and for the entire period of the survey, it may be concluded that An. gambiae vectors in Asutifi and Tano are capable of sustaining an infective 
biting pattern throughout the year. Some communities experienced higher malaria transmission than others, which is a clear indication of how local vector populations influence malaria intensity even when the communities are not very far apart, in most cases less than $5 \mathrm{~km}$ apart.

Anopheles funestus vectors has not be incriminated as a major vector in the studied area as the numbers caught in communities were low with negligible sporozoites rates.

Mining activities is reported to have an impact on malaria vector dynamics [19]. Environmental manipulation to accommodate project-related infrastructure developments can create favourable habitats for malaria vectors, most importantly An. gambiae [20]. The Ahafo area has experienced changes since mining activities commenced and therefore environmental changes might impact on vector densities. Also, mining activities attract several categories of workers and camp followers who might create settlements with poorly constructed houses and poor drainage creating conducive grounds for malaria transmission. The changes in behaviour of reservoir hosts and the ability of pathogens to adapt to new reservoir hosts in newly-created habitats also influence the patterns of disease [21]. Integrated vector control measures [22] are appropriate even more in the context of mining areas since the environment is greatly changed by mining and human activities. Continued malaria vector monitoring is, therefore, recommended in the ongoing mining areas in Tano and Asutifi.

\section{Conclusions}

The survey documented important malaria vector indices associated with a large mining development in a rural area. At the community level, malaria vector transmission is primarily determined by prevailing environment, housing characteristics and vector composition. Preventive measures, such as the use of treated bed nets or indoor residual spraying, need to be considered within the local context in order to maximize cost-effectiveness. For example high $k d r+$ levels in key mosquito vectors will impact the design and implementation of IRS and possibly even ITN distribution. Developing a pre-project baseline is critical and helps establish the underlying community situation and facilitates a scientifically rational control programme that can be sequentially monitored. It is in both the host communities and the project's best interest to have an objective foundation before active construction begins, during peak activity and for long-term continuous operations.

\section{Competing interests}

The authors declare that they have no competing interests.

\section{Authors' contributions}

All authors contributed equally to the planning and implementation of the study. The manuscript was drafted by DBD and KPA. All authors read and approved the final version for publication.

\section{Acknowledgements}

Our sincere gratitude goes to the individuals who agreed for traps to be set in their rooms. Same also goes to the chiefs and elders in communities for granting approval to enter their communities and Newmont Gold Ghana and the Ghana Health Service for support in carrying out this research.

\section{Author details}

${ }^{1}$ Kintampo Health Research Centre, Ghana Health Service, Ministry of Health, P.O. Box 200, Kintampo, Ghana. ${ }^{2}$ College of Health Sciences, University of Ghana, Legon, Ghana. ${ }^{3}$ Newmont Ghana Gold Limited, C825/26 Lagos Avenue, East Legon, Accra, Ghana. ${ }^{4}$ HealthLink Consulting, P.O. Box AN 6811, Accra-North, Ghana. ${ }^{5}$ Newfields, 730 17th Street, Suite 925, Denver, CO 80202, USA.

Received: 22 September 2014 Accepted: 25 March 2015

Published online: 07 April 2015

\section{References}

1. Zahar AR. Vector control operations in the African context. Bull World Health Organ. 1984;62(Suppl):89-100.

2. Binka FN, Mensah OA, Mills A. The cost-effectiveness of permethrin impregnated bednets in preventing child mortality in Kassena-Nankana district of Northern Ghana. Health Policy. 1997;41:229-39.

3. Klinkenberg E, McCall P, Wilson MD, Amerasinghe FP, Donnelly MJ. Impact of urban agriculture on malaria vectors in Accra. Ghana Malar J. 2008;4:151.

4. Moreno JE, Rubio-Palis Y, Páez E, Pérez E, Sánchez V. Abundance, biting behaviour and parous rate of anopheline mosquito species in relation to malaria incidence in gold-mining areas of southern Venezuela. Med Vet Entomol. 2007;21:339-49.

5. Hay SI, Guerra C, Tatem AJ, Atkinson PM, Snow RW. Urbanization, malaria transmission and disease burden in Africa. Nat Rev Microbiol. 2005;3:81-90.

6. Kelly-Hope LA, Hemingway J, McKenzie FE. Environmental factors associated with the malaria vectors Anopheles gambiae and Anopheles funestus in Kenya. Malar J. 2009;8:268.

7. Sutter PS. Nature's agents or agents of empire? Entomological workers and environmental change during the construction of the Panama Canal. In Isis. 2007:98:724-54.

8. Matthys B, Koudou BG, N'Goran EK, Vounatsou P, Gosoniu L, Koné M. Spatial dispersion and characterisation of mosquito breeding habitats in urban vegetable-production areas of Abidjan, Côte d'Ivoire. Ann Trop Med Parasitol. 2010;104:649-66.

9. Koram KA, Bennett S, Adiamah JH, Greenwood BM. Socio-economic risk factors for malaria in a peri-urban area of The Gambia. Trans R Soc Trop Med Hyg. 1995;89:146-50.

10. Palsson $\mathrm{K}$, Jaenson TG, Dias F, Laugen AT, Bjorkman A. Endophilic Anopheles mosquitoes in Guinea Bissau, west Africa, in relation to human housing conditions. J Med Entomol. 2004;41:746-52.

11. Gamage-Mendis AC, Carter R, Mendis C, De Zoysa AP, Herath PR, Mendis $\mathrm{KN}$. Clustering of malaria infections within an endemic population: risk of malaria associated with the type of housing construction. Am J Trop Med Hyg. 1991;45:77-85.

12. Flemming K, Priyanie A, Wim Van Der $H$, Amerasinghe F, Devika P, Maldeniya P. Strong association between house characteristics and malaria vectors in Sri Lanka. Am J Trop Med Hyg. 2003;68:177-81.

13. Atieli H, Menya D, Githeko A, Scott T. House design modifications reduce indoor resting malaria vector densities in rice irrigation scheme area in western Kenya. Malar J. 2009:19:108.

14. Asante KP, Zandoh C, Dery DB, Brown C, Adjei G, Antwi-Dadzie Y, et al. Malaria epidemiology in the Ahafo area of Ghana. Malar J. 2011;10:211.

15. Gilles MTDB. The Anophelinae of Africa South of Sahara (Ethiopian Zoogeographical Region). Publication of the South African Institute for Medical Research. 1968:54:127-50.

16. Robert W. Comparative testing of Plasmodium falciparum sporozoite monoclonal antibodies for ELISA development. Bull World Health Organ. 1987;65:39-45

17. Atieli H, Menya D, Githeko A, Scott T. House design modifications reduce indoor resting malaria vector densities in rice irrigation scheme area in western Kenya. Malar J. 2009:8:108.

18. Dery DB, Brown C, Asante KP, Adams M, Dosoo D, Amenga-Etego S, et al. Patterns and seasonality of malaria transmission in the forestsavannah transitional zones of Ghana. Malar J. 2010;9:314. 
19. Oyewole IO, Awolola TS. Impact of urbanisation on bionomics and distribution of malaria vectors in Lagos, southwestern Nigeria. J Vect Borne Dis. 2006;43:173-8

20. Cottrell G, Kouwaye B, Pierrat C, le Port A, Bouraima A, Fonton N, et al. Modeling the influence of local environmental factors on malaria transmission in Benin and its implications for cohort study. PLoS One. 2012;7:e28812.

21. Walsh JF, Molyneux DH, Birley MH. Deforestation: effects on vector-borne disease. Parasitology. 1993;106(Suppl):S55-75.

22. Beier JC, Keating J, Githure JI, Macdonald MB, Impoinvil DE, Novak RJ. Integrated vector management for malaria control. Malar J. 2008;7 Suppl 1:S4.

\section{Submit your next manuscript to BioMed Central} and take full advantage of:

- Convenient online submission

- Thorough peer review

- No space constraints or color figure charges

- Immediate publication on acceptance

- Inclusion in PubMed, CAS, Scopus and Google Scholar

- Research which is freely available for redistribution 